\title{
miR-21-5p confers doxorubicin resistance in gastric cancer cells by targeting PTEN and TIMP3
}

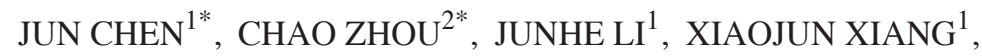 \\ $\mathrm{LING} \mathrm{ZHANG}^{1}$, JUN DENG ${ }^{1}$ and JIANPING XIONG ${ }^{1}$ \\ ${ }^{1}$ Department of Oncology, The First Affiliated Hospital of Nanchang University; \\ ${ }^{2}$ Department of Neurology, Jiangxi Provincial People's Hospital, Nanchang, Jiangxi 330006, P.R. China
}

Received February 20, 2017; Accepted January 4, 2018

DOI: $10.3892 / \mathrm{ijmm} .2018 .3405$

\begin{abstract}
Drug resistance and disease recurrence are major obstacles to the effective treatment of cancer, including gastric cancer (GC). However, the mechanisms of drug resistance remain to be fully elucidated. The present study investigated the roles of microRNA (miR)-21-5p in the doxorubicin (DOX) resistance of $\mathrm{GC}$ cells and the underlying mechanisms. miR-21-5p expression levels were identified to be inversely correlated with two well-known tumor suppressor genes, phosphatase and tensin homologue and tissue inhibitor of matrix metalloproteinases 3, and were upregulated in GC cell lines in proportion to their degree of resistance. Suppressing miR-21-5p expression partially sensitized SGC7901/DOX cells to DOX, suggesting that knockdown of miR-21-5p expression may be used as a therapeutic strategy to improve GC cell resistance. Importantly, increased miR-21-5p expression levels at diagnosis were correlated with clinicopathological characteristics including advanced stage and poor prognosis, further implying that a relapse of GC may be a consequence of miR-21-5p upregulation, thus providing evidence for the potential utility of miR-21-5p antagonism to sensitize GC cells to DOX chemotherapy.
\end{abstract}

\section{Introduction}

Gastric cancer (GC) is one of the major causes of malignant tumor-associated mortality worldwide (1). Although the application of surgery has markedly improved the prognosis for early-stage GC over the past decade, most patients who are

Correspondence to: Professor Jianping Xiong, Department of Oncology, The First Affiliated Hospital of Nanchang University, 17 Yongwaizheng Street, Nanchang, Jiangxi 330006, P.R. China

E-mail: xiong_jp@126.com

*Contributed equally

Key words: gastric cancer, doxorubicin resistance, miR-21-5p, PTEN, TIMP3 either diagnosed at an advanced stage or who have relapsed after an apparently curative operation still succumb to this cancer type, with an overall 5-year survival rate of $20 \%(2,3)$. Toxicity of combination chemotherapy and drug resistance remain challenges in successfully treating GC patients $(4,5)$. In addition, drug resistance is frequently observed in $\mathrm{GC}$ and other tumor types, but the details of this resistance have remained to be fully elucidated $(6,7)$.

In recent years, microRNAs (miRNAs/miRs), which are evolutionarily conserved small non-coding RNAs, were identified to have important roles in cell differentiation, apoptosis, proliferation and metabolism by inhibiting translation of mRNA or by promoting its degradation (8-12). Mounting evidence suggests that miRNAs are involved in tumorigenesis and progression, while they may have tumor suppressor or oncogenic roles (13-15). Furthermore, the influence of miRNAs on the tumor cell response to chemotherapeutic drugs has been reported in various malignancies (16-18). However, the role of miRNAs in drug resistance of GC has remained to be fully elucidated (19).

Recently, miR-21-5p has been of significant interest, as studies have demonstrated that it is frequently overexpressed in a wide variety of cancer types, including breast cancer (20), prostate cancer (21), lung cancer $(22,23)$, GC (24), pancreatic cancer (25), head and neck squamous cell carcinoma (26) and leukemia (27). In addition, it has been reported that dysregulation of miR-21-5p may be a predictor of tumor response to 5-fluorouracil, docetaxel and temozolomide (28-30). Although doxorubicin (DOX) is an unconventional chemotherapeutic drug for $\mathrm{GC}$, it is effective in certain cancer types, including leukemia, lymphoma and breast cancer. However, the functions and mechanisms of miR-21-5p in doxorubicin (DOX) drug resistance and relapse of GC have remained elusive.

The present study reported that the upregulation of miR-21-5p in clinical GC tissues is associated with an advanced clinical stage and a poor prognosis. Furthermore, miR-21-5p was identified to be upregulated in DOX-resistant $\mathrm{GC}$ cells. Inhibiting the expression of miR-21-5p may effectively reverse DOX resistance. In addition, the present study investigated the mechanisms of the roles of miR-21-5p in GC. The results suggested that miR-21-5p has an important role in DOX resistance of GC, with implications for cancer therapy. 


\section{Patients and methods}

Patients and clinical samples. Tissue samples from 46 patients with GC (tumor tissues and matched adjacent normal tissues as a control) and their clinical information were collected between January 2012 and December 2014 at the First Affiliated Hospital of Nanchang University (Nanchang, China). All patients received complete resection (D2 type) and did not receive chemotherapy or radiotherapy prior to surgery. In addition, certain patients received corresponding chemotherapy after surgery. The chemotherapeutic drugs included 5-fluorouracil, capecitabine and cisplatin. Patient characteristics are displayed in Table I. The study protocol was approved by the Ethics Committee of the First Affiliated Hospital of Nanchang University (Nanchang, China). Written informed consent was obtained from all participants.

Cell culture and DOX-resistant cell selection. The SGC7901 human gastric adenocarcinoma cell line (cat. no. TCHU46) and the HEK-293T human embryonic kidney cell line (cat. no. CRL-3216) were purchased from the Shanghai Institute of Biomedical Sciences (Shanghai, China) and the American Type Culture Collection (Manassas, VA, USA), respectively. Three DOX-resistant SGC7901 cell lines (SGC7901/DOX) were generated from parental SGC7901 cells by gradually treating them with $0.5,1$ and $2 \mu \mathrm{g} / \mathrm{ml}$ DOX for $>1$ month, as previously reported by Davies et al (31). Hence, these cells were named SGC7901/DOX-0.5 $\mu \mathrm{g} / \mathrm{ml}$, SGC7901/DOX-1 $\mu \mathrm{g} / \mathrm{ml}$ and SGC7901/DOX- $2 \mu \mathrm{g} / \mathrm{ml}$. SGC7901 and the selected SGC7901/DOX cell lines were cultured in Dulbecco's modified Eagle's medium (Gibco; Thermo Fisher Scientific, Inc., Waltham, MA, USA) containing $10 \%$ fetal bovine serum (HyClone; GE Healthcare, Little Chalfont, UK) at $37^{\circ} \mathrm{C}$ in a humidified atmosphere containing $5 \% \mathrm{CO}_{2}$ for further use.

RNA extraction and reverse transcription-quantitative polymerase chain reaction $(R T-q P C R)$ analysis. Total RNA was extracted from fresh GC tissue using RNAiso Plus (Takara Bio Inc., Otsu, Shiga Prefecture, Japan), and the RNA concentration and quality were detected with a NanoDrop-1000 spectrophotometer. RT-qPCR was then performed to detect miR-21-5p and its target mRNA expression levels. For RT-qPCR, $0.5 \mu \mathrm{g}$ total RNA were used to generate complementary DNA using the M-MLV Reverse Transcriptase kit (cat. no. RR037A; Takara Bio Inc.). RT was for $30 \mathrm{~min}$ at $16^{\circ} \mathrm{C}, 45 \mathrm{~min}$ at $42^{\circ} \mathrm{C}$ and $5 \mathrm{~min}$ at $85^{\circ} \mathrm{C}$. Then qPCR was performed to amplify the targets using the LightCycler ${ }^{\circledR} 480$ real-time PCR system (Roche Diagnostics, Basel, Switzerland) with specific mRNA/miRNA primers and SYBR $^{\circledR}$ Premix Ex Taq ${ }^{\mathrm{TM}}$ II reagents (cat. no. RR820A; Takara Bio Inc.) according to the manufacturer's protocol. Thermocycling conditions were as follows: $95^{\circ} \mathrm{C}$ for $3 \mathrm{~min}$ followed by 40 cycles of $95^{\circ} \mathrm{C}$ for $15 \mathrm{sec}$ and $60^{\circ} \mathrm{C}$ for $30 \mathrm{sec}$. The relative expression levels of mRNA and miRNA were determined using the $2^{-\Delta \Delta C q}$ method (32), with GAPDH and U6 used as internal controls separately. All PCRs were performed in triplicate. The sequences for all primers used in PCR are listed in Table II.

Cell transfection. All small molecular RNAs, including miR-21-5p mimics and scrambled oligonucleotides miR-negative control (NC), miR-21-5p antisense oligonucleotide
Table I. Characteristics of gastric cancer patients of the present study $(n=46)$.

\begin{tabular}{|c|c|c|}
\hline Characteristic & Median (range) & $\mathrm{n}(\%)$ \\
\hline Age at diagnosis (years) & $58(46-71)$ & \\
\hline$<60$ & & $20(43.5)$ \\
\hline$\geq 60$ & & $26(56.5)$ \\
\hline \multicolumn{3}{|l|}{ Sex } \\
\hline Male & & $25(54.3)$ \\
\hline Female & & $21(45.7)$ \\
\hline \multicolumn{3}{|l|}{ Differentiation } \\
\hline Well & & $16(34.8)$ \\
\hline Moderate & & $16(34.8)$ \\
\hline Poor & & $14(30.4)$ \\
\hline \multicolumn{3}{|l|}{ Metastasis } \\
\hline Yes & & $22(47.8)$ \\
\hline No & & $24(52.2)$ \\
\hline \multicolumn{3}{|c|}{ Tumor-nodes-metastasis stage } \\
\hline I+II & & $30(65.2)$ \\
\hline III+IV & & $16(34.8)$ \\
\hline \multicolumn{3}{|l|}{ After therapy $(\mathrm{n}=30)^{\mathrm{a}}$} \\
\hline Complete remission & & $17(56.7)$ \\
\hline Relapse or death & & $13(43.3)$ \\
\hline
\end{tabular}

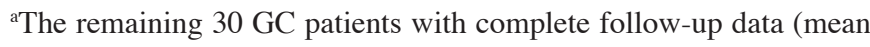
follow-up time, 39 months).

(anti-miR-21-5p) and its counterpart control (anti-miR-NC), and small interfering (si)RNA for the target mRNA were purchased from GenePharma Biotech (Shanghai, China).

These small RNAs were delivered into cultured cells using Lipofectamine $^{\circledR} 3000$ (Invitrogen; Thermo Fisher Scientific, Inc.). In brief, $3 \times 10^{5}$ cells were seeded in 6-well plates and grown to $75 \%$ confluence. All RNA transfections were performed at a final concentration of $50 \mathrm{nM}$ unless otherwise indicated according to the manufacturer's protocol. The transfection efficiency, which was assessed using a fluorescein amidite-conjugated siRNA (non-homologous to any human genome sequences; cat. no. A07001; GenePharma Biotech, Shanghai, China) and fluorescence-activated cell sorting (FACS) analysis, was determined to be $\sim 80 \%$ for GC cells (data not shown).

Measurement of drug sensitivity using the cell counting kit-8 (CCK-8) assay. The transfected cells were cultured in 96-well plates at $5 \times 10^{3}$ cells per well in $100 \mu \mathrm{l}$ medium and were maintained overnight, followed by exposure to various concentrations of DOX for $48 \mathrm{~h}$. Cell viability was monitored using a CCK-8 (Dojindo, Kumamoto, Japan). In brief, $10 \mu \mathrm{l}$ CCK-8 stain was added to each well of the plate, followed by incubation for $2 \mathrm{~h}$ and measurement of the absorbance at 450 and $630 \mathrm{~nm}$ (reference wavelength) using a microplate reader. The concentration causing 50\% inhibition of growth $\left(\mathrm{IC}_{50}\right)$ of the drug was estimated from a relative survival curve. All experiments were performed three times. 
Table II. Primers and other oligonucleotides sequences.

\begin{tabular}{|c|c|c|}
\hline Name & Sequence $\left(5^{\prime}-3^{\prime}\right)$ & $\begin{array}{c}\text { Product } \\
\text { length (bp) }\end{array}$ \\
\hline miR-21-5p-RT & $\begin{array}{l}\text { GTCGTATCCAGTGCAGGGTCCGAGGTATTCG } \\
\text { CACTGGATACGACTCAACA }\end{array}$ & \\
\hline $\begin{array}{l}\operatorname{miR}-21-5 p-F \\
\operatorname{miR}-21-5 p-R\end{array}$ & $\begin{array}{l}\text { GCACCTAGCTTATCAGACTGA } \\
\text { GTGCAGGGTCCGAGGT }\end{array}$ & 22 \\
\hline $\begin{array}{l}\text { U6-F } \\
\text { U6-R }\end{array}$ & $\begin{array}{l}\text { CTCGCTTGGCAGCACATATACT } \\
\text { ACGCTTCACGAATTTGCGTGTC }\end{array}$ & 90 \\
\hline PTEN-3'UTR-F & $\begin{array}{l}\text { GCTTTGGTGGTAGTACTCTGGTTGTTAAGCT } \\
\text { AGGTATTTTGAGACTACTTCCCCATCAC }\end{array}$ & 59 \\
\hline PTEN-3'UTR-R & $\begin{array}{l}\text { GTGATGGGGAAGTAGTCTCAAAATACCTAGC } \\
\text { TTAACAACCAGAGTACTACCACCAAAGC }\end{array}$ & \\
\hline MUT-PTEN-F & $\begin{array}{l}\text { GCTTTGGTGGTAGTACTCTGGTTGTATTCGAT } \\
\text { GGTATTTTGAGACTACTTCCCCATCAC }\end{array}$ & 59 \\
\hline MUT-PTEN- R & $\begin{array}{l}\text { GTGATGGGGAAGTAGTCTCAAAATACCATCG } \\
\text { AATACAACCAGAGTACTACCACCAAAGC }\end{array}$ & \\
\hline TIMP3-3'UTR(1)-F & $\begin{array}{l}\text { TTGCATATACCCACATGGGGACATAAGCTAA } \\
\text { TTTTTTTACAGGACACAGAATTCTGT }\end{array}$ & 59 \\
\hline TIMP3-3'UTR(1)-R & $\begin{array}{l}\text { ACAGAATTCTGTGTCCTGTAAAAAAATTAGC } \\
\text { TTATGTCCCCATGTGGGTATATGCAA }\end{array}$ & \\
\hline MUT-TIMP3(1)-F & $\begin{array}{l}\text { TTGCATATACCCACATGGGGACAATTCGATAT } \\
\text { TTTTTTACAGGACACAGAATTCTGT }\end{array}$ & 59 \\
\hline MUT-TIMP3(1)-R & $\begin{array}{l}\text { ACAGAATTCTGTGTCCTGTAAAAAAATATCG } \\
\text { AATTGTCCCCATGTGGGTATATGCAA }\end{array}$ & \\
\hline TIMP3-3'UTR(2)-F & $\begin{array}{l}\text { CGATGTCAGAGGGCGGTTTTGAGCTTTCTATA } \\
\text { AGCTATAGCTTTGTTTATTTCACCCGT }\end{array}$ & 59 \\
\hline TIMP3-3'UTR(2)-R & $\begin{array}{l}\text { ACGGGTGAAATAAACAAAGCTATAGCTTATA } \\
\text { GAAAGCTCAAAACCGCCCTCTGACATCG }\end{array}$ & \\
\hline MUT-TIMP3(2)-F & $\begin{array}{l}\text { CGATGTCAGAGGGCGGTTTTGAGCTTTCTAA } \\
\text { TTCGATTAGCTTTGTTTATTTCACCCGT }\end{array}$ & 59 \\
\hline MUT-TIMP3(2)-R & $\begin{array}{l}\text { ACGGGTGAAATAAACAAAGCTAATCGAATTA } \\
\text { GAAAGCTCAAAACCGCCCTCTGACATCG }\end{array}$ & \\
\hline $\begin{array}{l}\text { PTEN-F } \\
\text { PTEN-R }\end{array}$ & $\begin{array}{l}\text { GCCCAGACTGCATACGAT } \\
\text { CCTAATCTATTTGCCATCAA }\end{array}$ & 294 \\
\hline $\begin{array}{l}\text { TIMP3-F } \\
\text { TIMP3-R }\end{array}$ & $\begin{array}{l}\text { TACCTGCCTTGCTTTGTG } \\
\text { CATCTGGGAAGAGTTAGTGTC }\end{array}$ & 257 \\
\hline $\begin{array}{l}\text { Pre-miR-21-5p-F } \\
\text { Pre-miR-21-5p-R }\end{array}$ & $\begin{array}{l}\text { CGCGGATCCGCATGGCAACACCAGTCGA } \\
\text { CCGCTCGAGTTGTCAGACAGCCCATCGA }\end{array}$ & 42 \\
\hline $\begin{array}{l}\text { GAPDH-F } \\
\text { GAPDH-R }\end{array}$ & $\begin{array}{l}\text { GCTGAACGGGAAGCTCACTG } \\
\text { GTGCTCAGTGTAGCCCAGGA }\end{array}$ & 169 \\
\hline
\end{tabular}

F, forward primer; R, reverse primer; RT, reverse transcription primer; PTEN, phosphatase and tensin homologue; TIMP3, tissue inhibitor of matrix metalloproteinases 3; miR, microRNA; MUT, mutated; UTR, untranslated region.

Apoptosis assay. Apoptosis was assessed using an Annexin V-fluorescein isothiocyanate (FITC) apoptosis kit (cat. no. K101-100; Biovision, Milpitas, CA, USA). Cells were washed with ice-cold PBS and re-suspended in $1 \mathrm{X}$ Annexin V binding solution at a concentration of $1 \times 10^{6}$ cells $/ \mathrm{ml}$. The cells were then collected and stained with $5 \mu \mathrm{l}$ Annexin V-FITC and $5 \mu \mathrm{l}$ propidium iodide for $15 \mathrm{~min}$ at room temperature in the dark prior to analysis with a FACSCalibur instrument (BD Biosciences, Franklin Lakes, NJ, USA). The collected data were analyzed using FlowJo V10.1 software (BD Biosciences).

Target gene prediction. Four computer programs/algorithms, namely Targetscan (http://www.targetscan.org), starBase v2.0 (http://starbase.sysu.edu.cn/), miRBase (http://www.mirbase. 
org/index.shtml) and PICTAR (http://pictar.mdc-berlin.de), were used to predict the targets of miR-21-5p. To overcome the limitations of each program, the putative target genes predicted by at least three of the programs were selected for further experimental analyses.

Construction of the vector and luciferase reporter assay. The expression vector for miR-21-5p (pcDNA-miR-21-5p) was generated by cloning the genomic fragments encompassing the corresponding miR-21-5p precursor and its 5'- and 3'-flanking sequences into the pcDNA6.2 plasmid (cat. no. K246020; Invitrogen; Thermo Fisher Scientific, Inc., Waltham, MA, USA). Fragments of the 3'-untranslated region (UTR) of potential target mRNAs containing putative binding sites for miR-21-5p were inserted downstream of the stop codon of Firefly luciferase in the psi-Check 2 vector (cat. no. C8021; Promega Corp., Madison, WI, USA) as previously described (33). To yield mutant constructs, mutations were introduced in the potential miR-21-5p binding sites using the QuikChange Site-directed Mutagenesis kit (cat. no. 210515; Stratagene, San Diego, CA, USA). The luciferase reporter constructs and pcDNA-miR-21-5p (or empty plasmid) were co-transfected into HEK-293T cells in a 48-well plate for reporter assays using Lipofectamine ${ }^{\mathrm{TM}} 3000$ (Invitrogen; Thermo Fisher Scientific, Inc.), respectively. Renilla and Firefly luciferase activities were assayed using the Dual-Luciferase ${ }^{\circledR}$ Reporter 1000 assay system (cat. no. E1960; Promega Corp.). The effect of miR-21-5p on target gene expression was detected by calculating the relative value of Firefly luciferase activity normalized to Renilla luciferase activity.

Western blot analysis. Cells were harvested at $48 \mathrm{~h}$ after transfection, washed with PBS and lysed in radioimmunoprecipitation assay buffer (Thermo Fisher Scientific, Inc.) supplemented with protease inhibitors (cat. no. 04693132001; Roche Diagnostics) for $30 \mathrm{~min}$ at $4^{\circ} \mathrm{C}$ prior to centrifugation. Subsequently, the concentration was measured using the BCA Protein assay kit (cat. no. 23225; Pierce; Thermo Fisher Scientific, Inc.). Equal amounts of protein $(20 \mu \mathrm{g})$ were separated by $10 \%$ SDS-PAGE and then transferred onto polyvinylidene difluoride membranes (EMD Millipore, Billerica, MA, USA). Membranes were blocked for $2 \mathrm{~h}$ at room temperature by using bovine serum albumin (cat. no. SW3015-500 ml; Beijing Solarbio Science and Technology Co., Ltd., Beijing, China), the membranes were incubated overnight at $4^{\circ} \mathrm{C}$ with anti-phosphatase and tensin homologue (PTEN) antibody (cat. no. 14642; 1:1,000), anti-tissue inhibitor of matrix metalloproteinases 3 (TIMP3) antibody (cat. no. 5673; 1:1,000), anti-tubulin antibody (cat. no. 2146; 1:2,000 all from Cell Signaling Technology, Inc., Danvers, MA, USA), or anti-GAPDH antibody (cat. no. 60004-1-1 g; 1:5,000) followed by horseradish peroxidase-linked secondary antibodies (cat nos. SA00006-2 and SA00001-1; 1:5,000; all from Proteintech, Wuhan, China) for $1 \mathrm{~h}$ at room temperature. Proteins were then visualized with a chemiluminescence detection system (cat. no. WBKLSO100; EMD Millipore). The experiments were performed at least three times.

Statistical analysis. Statistical analyses were performed with GraphPad Prism 6.0 software (GraphPad Inc., La Jolla, CA,
A

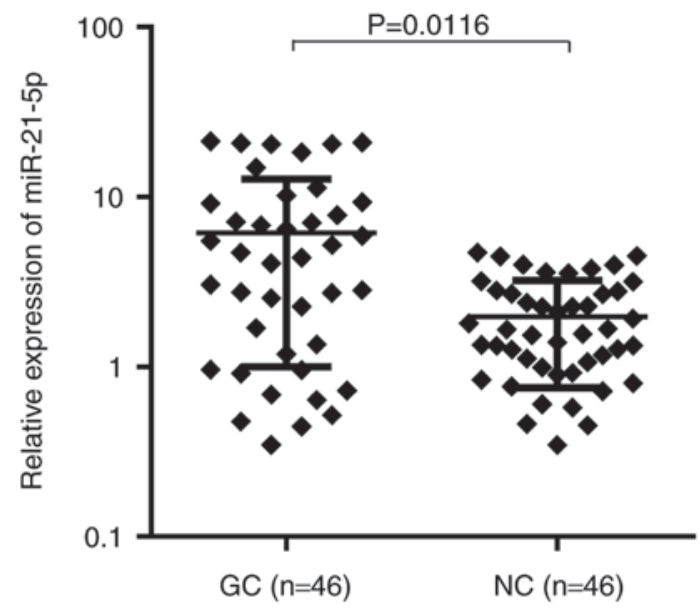

B

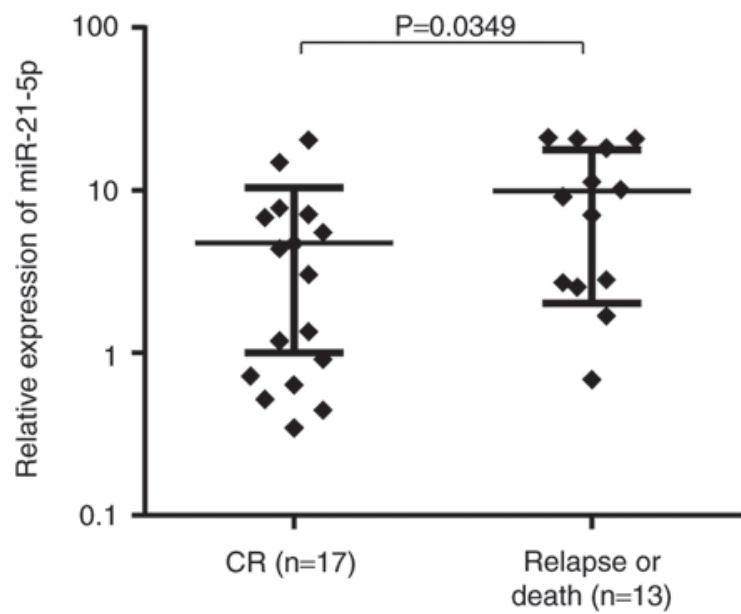

Figure 1. Differential expression of miR-21-5p in GC patients. (A) Relative expression of miR-21-5p (normalized to U6) in GC and matched adjacent NC tissues was measured by reverse transcription quantitative-polymerase chain reaction analysis. (B) Primary GC samples $(n=30)$ were divided according to clinical outcomes. Patients who developed distant recurrence or succumbed had significantly higher miR-21-5p expression than those who had CR after treatment. CR, complete remission; miR, microRNA; NC, normal control; $\mathrm{GC}$, gastric cancer.

USA). The cytological experiments were performed at least in triplicate and all values are expressed as the mean \pm standard deviation. Differences between groups were analyzed using Student's t-test when only two groups were present, and in the case of more than two groups, one-way analysis of variance followed by a post-hoc multiple comparisons test (least-significant differences test) was applied. Unless otherwise noted, differences in mRNA/miRNA expression in clinical samples between two groups were analyzed using the Mann-Whitney $\mathrm{U}$ test for independent unpaired samples, and paired samples were analyzed using the Wilcoxon test. The $\chi^{2}$ or Fisher's exact test were used to analyze categorical variables. Correlations were determined using Spearman correlation analysis. $\mathrm{P}<0.05$ was considered to indicate a statistically significant difference.

\section{Results}

Upregulation of miR-21-5p in clinical GC tissue is correlated with an advanced clinical stage and poor prognosis. In a previous study (34), differential miRNA expression profiles 
Table III. Characteristics of gastric cancer patients in association with miR-21-5p expression levels.

\begin{tabular}{|c|c|c|c|c|}
\hline \multirow[b]{2}{*}{ Parameter } & \multirow[b]{2}{*}{ Total (n) } & \multicolumn{2}{|c|}{$\operatorname{miR}-21-5 p$} & \multirow[b]{2}{*}{ P-value } \\
\hline & & Low expression $(\mathrm{n})$ & High expression (n) & \\
\hline Age at diagnosis (years) & & & & 0.234 \\
\hline$<60$ & 20 & 12 & 8 & \\
\hline$\geq 60$ & 26 & 11 & 15 & \\
\hline Sex & & & & 0.375 \\
\hline Male & 25 & 14 & 11 & \\
\hline Female & 21 & 9 & 12 & \\
\hline Differentiation & & & & $0.017^{\mathrm{a}}$ \\
\hline Well & 16 & 9 & 7 & \\
\hline Moderate & 16 & 10 & 6 & \\
\hline Poor & 14 & 2 & 12 & \\
\hline Metastasis & & & & $0.013^{\mathrm{a}}$ \\
\hline Yes & 22 & 4 & 18 & \\
\hline No & 24 & 14 & 10 & \\
\hline Tumor-nodes-metastasis stage & & & & $0.047^{\mathrm{a}}$ \\
\hline $\mathrm{I}+\mathrm{II}$ & 30 & 20 & 10 & \\
\hline III+IV & 16 & 5 & 11 & \\
\hline
\end{tabular}

aDetermined by a two-sided Fisher's exact test. miR, microRNA.

revealed dysregulation of miR-21-5p in GC tissues. To further confirm this result, the present study examined miR-21-5p expression levels in primary tumor samples from a GC patient cohort $(n=46)$. miR-21-5p expression in GC tissue was 3.91-fold (range, 0.031-72.429) higher than that in matched adjacent NC tissues ( $\mathrm{P}=0.0116$; Fig. 1A). The median values of relative miR-21-5p expression in the GC and NC tissues were 4.03 and 1.27 , respectively. Of these $46 \mathrm{GC}$ patients, $24(52.2 \%)$ exhibited a tumor tissue-specific upregulation of miR-21-5p expression levels by $>2$-fold. To determine whether miR-21-5p expression correlates with clinical characteristics of GC patients, the patients were stratified into high and low expression groups according to the median value of miR-21-5p expression. As indicated in Table III, a statistically significant correlation between miR-21-5p expression and available pathological parameters was identified, including differentiation status, lymph node metastasis and tumor-nodes-metastasis (TNM) stage of GC.

Of the 46 primary patients, $16(34.8 \%)$ received treatment and were then lost to follow-up. The remaining $30 \mathrm{GC}$ patients $(65.2 \%)$ with complete follow-up data (mean follow-up time, 39 months) were divided into two groups based on prognosis. The miR-21-5p expression levels at diagnosis in the patients who suffered from relapse or death $(n=13)$ was significantly higher than that of the remaining 17 patients in continuous complete remission ( $\mathrm{CR}$; $\mathrm{P}=0.0349$; Fig. $1 \mathrm{~B}$ ). These results collectively indicate that higher miR-21-5p expression in GC patients is correlated with an advanced clinical stage and a poor prognosis.

miR-21-5p expression is dysregulated in DOX-resistant SGC7901/DOX cells. The survival curves of the three SGC7901/DOX cell lines and the parental cell line SGC7901 are illustrated in Fig. 2A. The results indicated that the three SGC7901/DOX cell lines, SGC7901/DOX-0.5 $\mu \mathrm{g} / \mathrm{ml}$, SGC7901/DOX-1 $\mu \mathrm{g} / \mathrm{ml}$ and SGC7901/DOX-2 $\mu \mathrm{g} / \mathrm{ml}$ had a 1.4-, 2.1- and 3.3-fold acquired resistance to DOX, respectively, based on their $\mathrm{IC}_{50}$ values $(\mathrm{P}<0.05$; Fig. $2 \mathrm{~B})$. Next, the miR-21-5p expression levels were determined in the three DOX-resistant cell lines to further elucidate whether miR-21-5p expression affects DOX resistance. The results indicated that miR-21-5p was least expressed in the SGC7901 cells, while the expression levels gradually increased in the three DOX-resistant cell lines with increasing DOX tolerance levels $(\mathrm{P}<0.05$; Fig. $2 \mathrm{C})$, suggesting that miR-21-5p may be associated with DOX resistance of GC cells. As SGC7901/DOX- $2 \mu \mathrm{g} / \mathrm{ml}$ exhibited the greatest resistance to DOX, this cell line was used for the subsequent experiments.

Suppression of miR-21-5p expression sensitizes SGC7901/DOX cells to DOX. To elucidate the association between miR-21-5p and DOX resistance in GC cells, miR-21-5p antagomir (anti-miR-21) was transfected into SGC7901/DOX-2 $\mu \mathrm{g} / \mathrm{ml}$ to specifically inhibit the expression of miR-21-5p. The miR-21-5p expression in the miR-21 inhibitor group was reduced to $44.8 \%$ of that in the corresponding control group $(\mathrm{P}<0.05$; Fig. $3 \mathrm{~A})$, and the anti-miR-21-transfected group of SGC7901/DOX-2 $\mu \mathrm{g} / \mathrm{ml}$ cells exhibited a significantly lower survival rate upon exposure to DOX compared with that of the control-transfected group.Furthermore, the $\mathrm{IC}_{50}$ value was determined to be $1.443 \pm 0.017 \mu \mathrm{g} / \mathrm{ml}$ for the anti-miR-21 group and 3.985 $\pm 0.064 \mu \mathrm{g} / \mathrm{ml}$ for the anti-miR-NC group $(\mathrm{P}<0.05$; Fig. 3B). In addition, it was demonstrated that in SGC7901/DOX-2 $\mu \mathrm{g} / \mathrm{ml}$ cells, transfection with anti-miR-21 enhanced DOX-induced apoptosis following DOX treatment at $1 \mu \mathrm{g} / \mathrm{ml}$ for $48 \mathrm{~h}(\mathrm{P}<0.05$; Fig. $3 \mathrm{C})$. These results indicate that knockdown of miR-21-5p increased DOX sensitivity in 

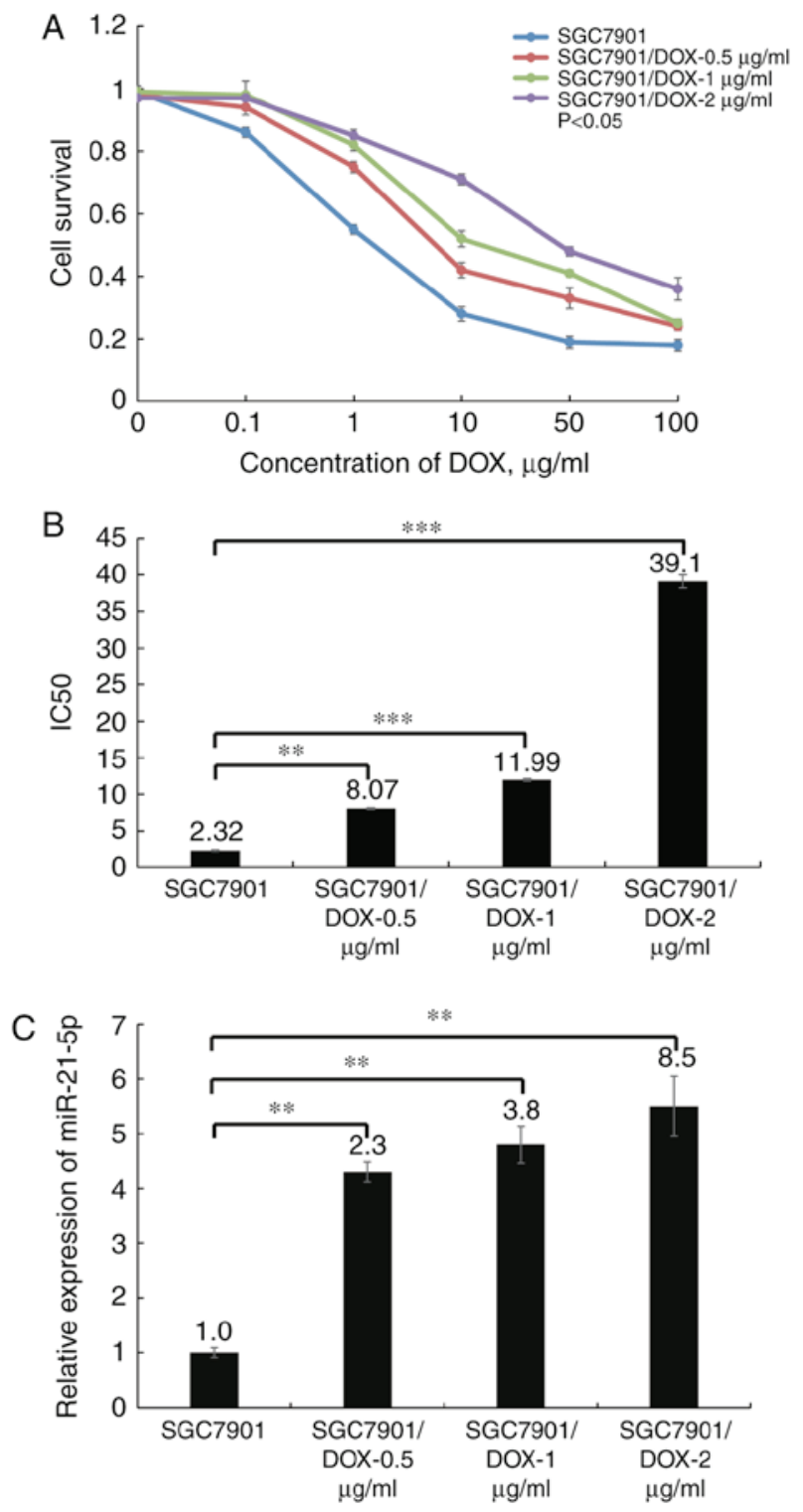

Figure 2. Expression levels of miR-21-5p in SGC7901 and SGC7901/DOX cells. (A) Native SGC7901 cells those with acquired resistance to three different concentrations of DOX were incubated with various doses of DOX for $48 \mathrm{~h}$, and the cell viability was determined using a cell counting kit- 8 assay. (B) The $\mathrm{IC}_{50}$ values of SGC7901 and three DOX-resistant cell lines were calculated. (C) Reverse transcription quantitative-polymerase chain reaction analysis indicated that miR-21-5p was significantly upregulated in SGC7901/DOX cells compared with those in SGC7901 cells. ${ }^{* *} \mathrm{P}<0.01$ and ${ }^{* * *} \mathrm{P}<0.001$. DOX, doxorubicin; SGC7901/DOX, DOX-resistant SGC7901 cell line; $\mathrm{IC}_{50}$, concentration causing 50\% growth inhibition; miR, microRNA.

SGC7901/DOX-2 $\mu \mathrm{g} / \mathrm{ml}$ cells; thus, it was hypothesized that antagonism of miR-21-5p partially reversed DOX resistance in these cells.

Upregulation of $\mathrm{miR}-21-5 \mathrm{p}$ renders $S G C 7901$ cells resistant to DOX. Based on the above evidence, the present study further investigated the effects of miR-21 in SGC7901 cells. The miR-21-5p expression levels were significantly elevated following transfection with miR-21-5p mimics $(\mathrm{P}<0.001$; Fig. 4A). Next, the cell viability was examined with the goal of determining whether overexpression of miR-21-5p affects the sensitivity of SGC7901 cells to DOX. A dose-dependent growth inhibition of SGC7901 cells in response to DOX was observed, and cells transfected with miR-21 mimics exhibited significantly lower DOX sensitivity than those transfected with miR-NC $\left(\mathrm{P}<0.05\right.$; Fig. 4B). The $\mathrm{IC}_{50}$ of DOX in the former group was higher than that in the latter group. In addition, overexpression of miR-21-5p rendered SGC7901 cells more resistant to DOX-induced apoptosis upon DOX treatment $(\mathrm{P}<0.05$; Fig. 4C). Taken together, these results suggest that miR-21-5p has an important role in DOX resistance of GC cells.

miR-21-5p mediates apoptosis by targeting PTEN and TIMP3. The predicted targets of miR-21-5p are PTEN and TIMP3, which were identified by using several miRNA target gene prediction websites. The 3'UTR of PTEN and TIMP3 contains one and two putative miR-21-5p-binding sites, respectively (Fig. 5A). To verify this, three plasmids were generated by cloning the respective fragments from the 3'-UTR of PTEN or TIMP3 into the downstream region of the Renilla luciferase reporter gene. HEK-293T cells were then co-transfected with one of the wild type or mutant reporter vectors and precursor miR-21-5p or miR-NC. A significant reduction of luciferase activity of the wild-type reporter vector was observed in the presence of miR-21-5p. Conversely, partial mutation of the respective seed regions blocked the ability of miR-21-5p to inhibit luciferase activity ( $\mathrm{P}<0.05$; Fig. 5B). In addition, PTEN protein was significantly downregulated in miR-21-5p mimics-transfected cells, but was significantly increased in inhibitor-transfected cells (Fig. 5C). Similar results were also observed for TIMP3 (Fig. 5D). Taken together, these results indicated that miR-21-5p directly regulates PTEN and TIMP3 as target mRNAs in GC cells.

Knockdown of PTEN and TIMP3 enhances DOX resistance of SGC7901 cells. Next, the present study sought to determine whether direct knockdown of PTEN or TIMP3 confers cellular DOX resistance, similar to the effect of miR-21-5p mimics. First, SGC7901 cells were depleted of endogenous PTEN or TIMP3 by transfection of specific siRNA. The transfection efficiency was confirmed through RT-qPCR and western blot analysis (Fig. 6A-D). Silencing of PTEN or TIMP3 mRNA caused significant inhibition of the corresponding mRNA and protein expression in SGC7901 cells. The cell survival assay revealed that DOX resistance was significantly increased in siRNA-PTEN- or siRNA-TIMP3-transfected cells compared with that of cells transfected with control siRNA (Fig. 6E). All of these results mirrored those obtained by transfection of miR-21-5p and further suggested that the effects of miR-21-5p on DOX resistance in GC cells may be mediated by targeting PTEN and TIMP3.

Clinical relevance of miR-21-5p and PTEN or TIMP3 in $G C$ patients. To assess the clinical relevance of miR-21-5p and PTEN or TIMP3 in GC patients, PTEN and TIMP3 mRNA levels were first detected in newly diagnosed GC patients, and the possible correlation between miR-21-5p and the target genes was then evaluated. As presented in Fig. 7A and B, PTEN and TIMP3 were significantly downregulated in $\mathrm{GC}$ patients $(\mathrm{P}<0.01)$. Furthermore, a significantly inverse correlation between miR-21-5p expression and PTEN levels 
A

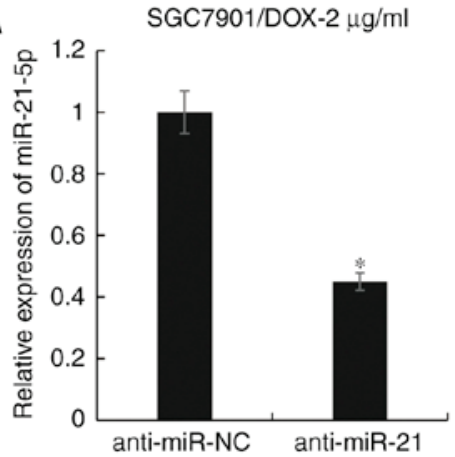

B

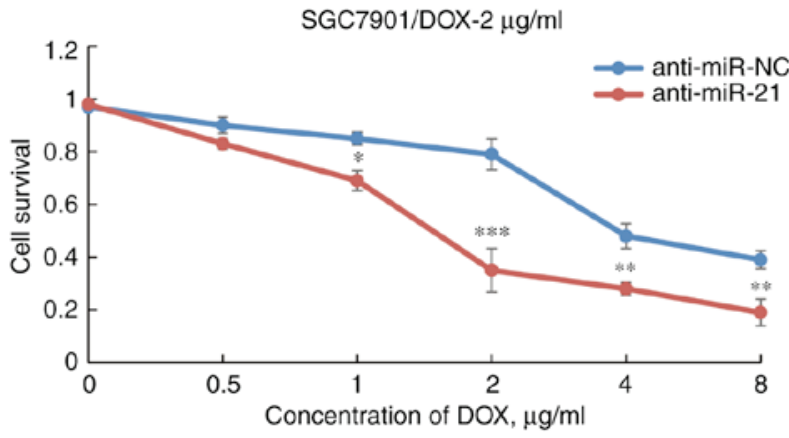

C

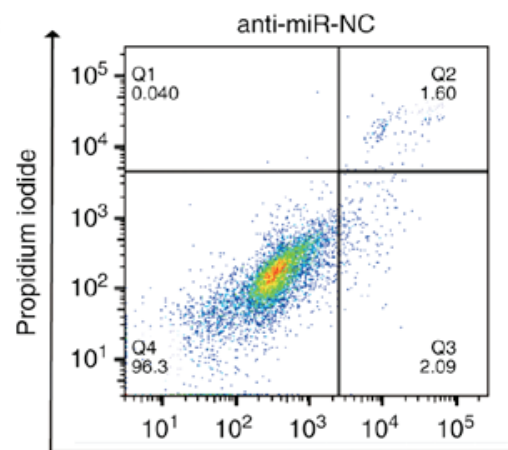

anti-miR-21

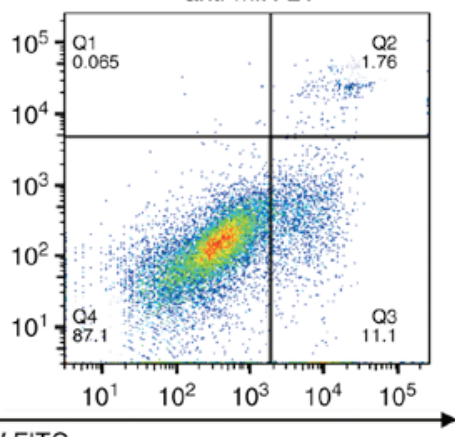

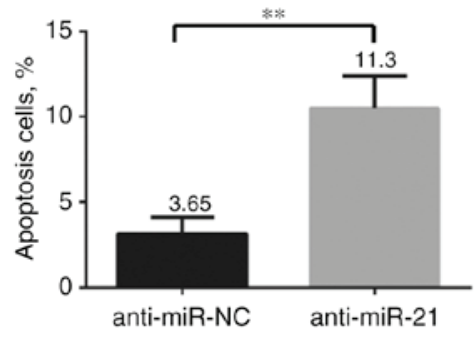

Figure 3. Effect of miR-21-5p antagomir on DOX sensitivity of SGC7901/DOX-2 $\mu \mathrm{g} / \mathrm{ml}$ cells. (A) Transfection of anti-miR-21 decreased miR-21-5p expression levels in SGC7901/DOX-2 $\mu \mathrm{g} / \mathrm{ml}$ cells to $44.8 \%$ of those in the anti-miR-NC group. (B) After transfection of SGC7901/DOX cells with anti-miR-21 or anti-miR-NC for $24 \mathrm{~h}$ and treatment with various doses of DOX for $48 \mathrm{~h}$, the cell viability was assessed. (C) Flow cytometric analysis determined the influence of miR-21-5p on the apoptosis of SGC7901/DOX-2 $\mu \mathrm{g} / \mathrm{ml}$ cells following treatment with DOX (1 $\mu \mathrm{g} / \mathrm{ml})$ for $48 \mathrm{~h}$. The proportions of dead cells (Q1: Annexin V-FITC-PI $\left.{ }^{+}\right)$, late apoptotic or necrotic cells $\left(\mathrm{Q} 2\right.$ : Annexin $\left.\mathrm{V}-\mathrm{FITC}^{+} / \mathrm{PI}^{+}\right)$, early apoptotic cells $\left(\mathrm{Q} 3\right.$ : Annexin $\left.\mathrm{V}-\mathrm{FITC}^{+} / \mathrm{PI}\right)$ and live cells (Q4: Annexin V-FITC $/ \mathrm{PI}-$ ) are displayed. ${ }^{*} \mathrm{P}<0.05,{ }^{* *} \mathrm{P}<0.01$ and ${ }^{* * * *} \mathrm{P}<0.001$ vs. anti-miR-NC. miR, microRNA; FITC, fluorescein isothiocyanate; $\mathrm{PI}$, propidium iodide; DOX, doxorubicin; SGC7901/DOX, DOX-resistant SGC7901 cell line; NC, negative control; Q, quadrant.

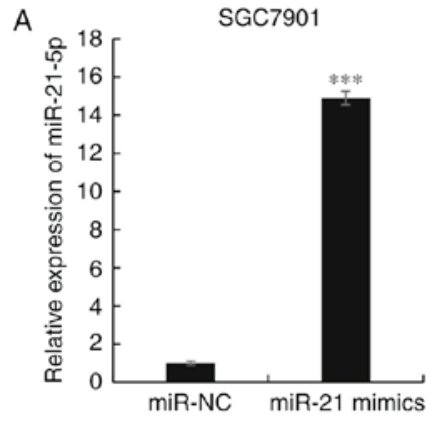

$\mathrm{C}$

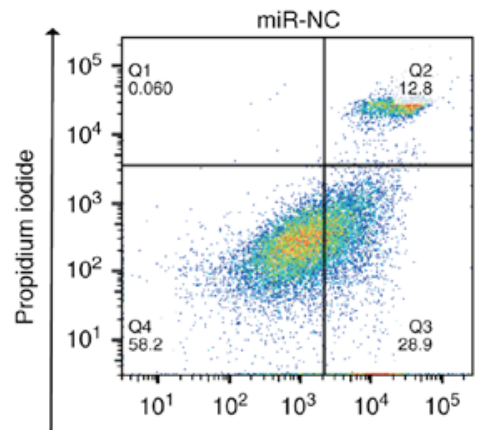

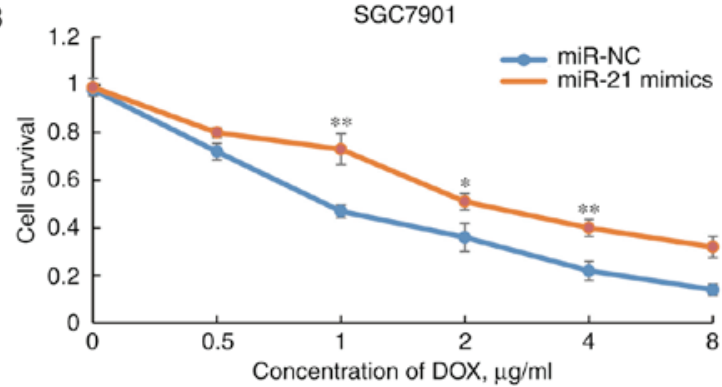

miR-21 mimics

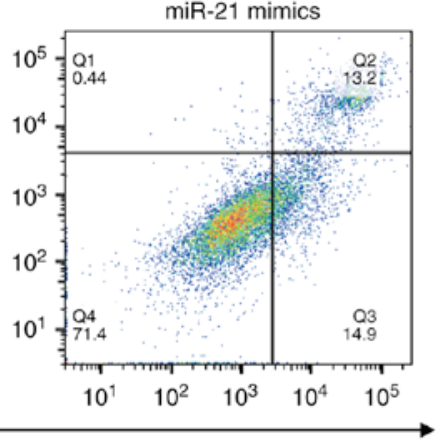

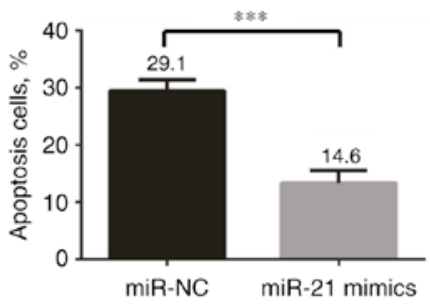

Annexin-V-FITC

Figure 4. Overexpression of miR-21 increases DOX resistance of SGC7901 cells. (A) A reverse transcription quantitative-polymerase chain reaction assay was performed to examine miR-21-5p expression levels after transfection of its mimics (or miR-NC). (B) A cell counting kit-8 assay was used to determine the viability of SGC7901 cells after transfection with miR-21 mimics (or miR-NC) following exposure to various doses of DOX for 48 h. (C) Apoptotic rates of SGC7901 cells were analyzed to determine the role of miR-21-5p on the effects of DOX treatment (1 $\mu \mathrm{g} / \mathrm{ml})$ for $48 \mathrm{~h}$. Late apoptotic or necrotic cells and early apoptotic cells are displayed in $\mathrm{Q} 2$ and $\mathrm{Q} 3$, respectively. ${ }^{*} \mathrm{P}<0.05,{ }^{* *} \mathrm{P}<0.01$ and ${ }^{* * * *} \mathrm{P}<0.001$ vs. miR-NC. miR, microRNA; FITC, fluorescein isothiocyanate; DOX, doxorubicin; NC, negative control; Q, quadrant. 
A

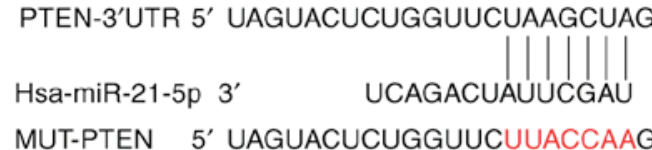

TIMP3-3'UTR(1) 5' UACCCACAUGGGACAUAAGCUA Hsa-miR-21-5p $\quad 3^{\prime} \quad$ UCAGACUAUUCGAU MUT-TIMP3(1) 5' UACCCACAUGGGACAUUACCAA

TIMP3-3'UTR(2) 5' GGUUUUGAGCUUUCUAUAAGCUA Hsa-miR-21-5p $\quad 3^{\prime} \quad$ UCAGACUAUUCGAU MUT-TIMP3(2) 5' GGUUUUGAGCUUUCUAUUACCAA

$C_{54 k}$
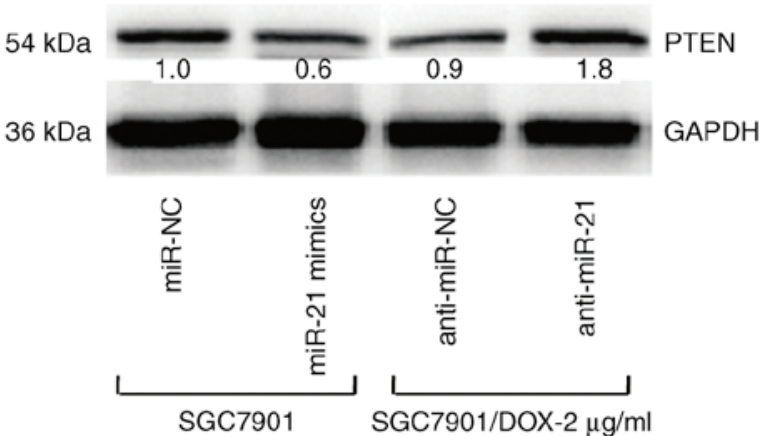
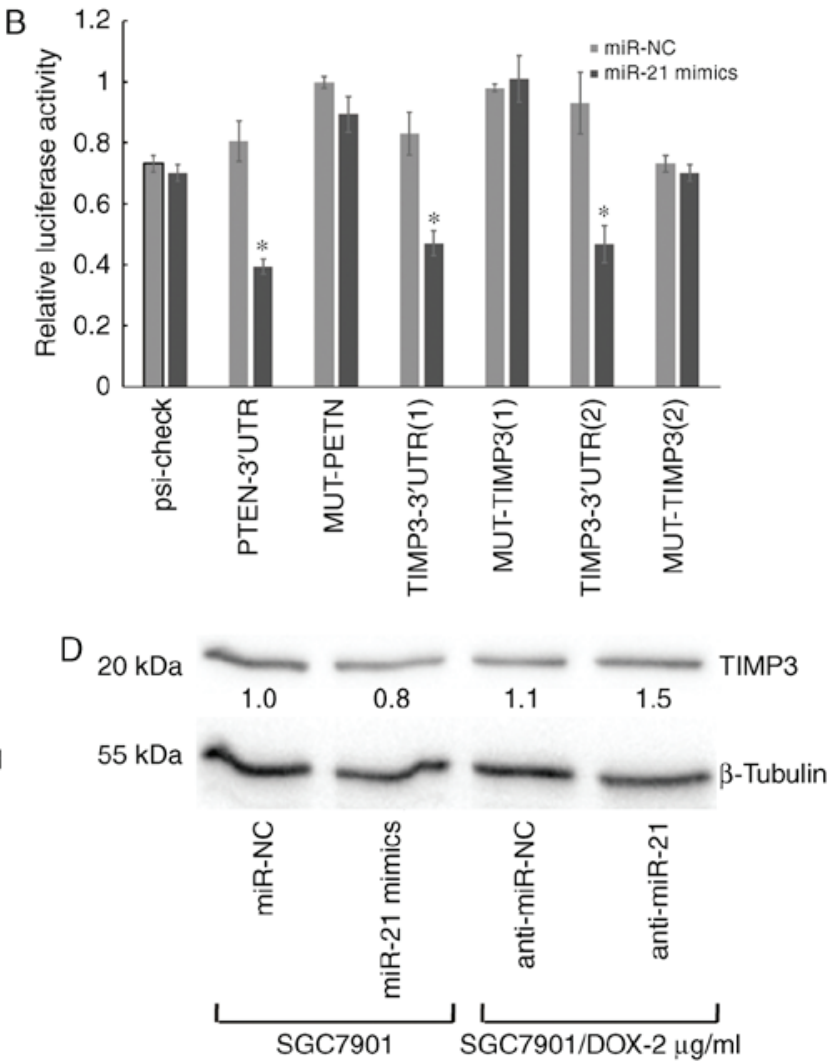

Figure 5. PTEN and TIMP3 are targets of miR-21-5p. (A) The 3'-UTRs of PTEN and TIMP3 were identified as putative targets of miR-21-5p with 7-mer or 8-mer complementarity regions. Seven nucleotides in the miR-21-5p seed region (gray font) were mutated using polymerase chain reaction site-directed mutagenesis. (B) A dual-luciferase reporter assay was performed to assess the influence of miR-21-5p on luciferase intensity controlled by the 3'-UTR of potential targets. (C and D) Western blot analysis indicated a decrease or increase in PTEN and TIMP3 protein levels following transfection of miR-21 mimics or anti-miR-21, respectively. Western blot images are representative of at least three independent experiments. The value under each sample indicates the fold change of PTEN or TIMP3 protein levels relative to the control. ${ }^{*} \mathrm{P}<0.05$ vs. miR-NC. PTEN, phosphatase and tensin homologue; TIMP3, tissue inhibitor of matrix metalloproteinases 3; UTR, untranslated region; miR, microRNA; NC, negative control; Hsa, Homo sapiens; MUT, mutant; SGC7901/DOX, doxorubicin-resistant SGC7901 cell line.

was observed in this cohort $(\mathrm{r}=-0.4175, \mathrm{P}=0.0039)$. In addition, a statistically significant correlation between miR-21-5p levels and TIMP3 expression was identified in the GC samples examined $(\mathrm{r}=-0.3263, \mathrm{P}=0.004)$. This result suggests that PTEN and TIMP3 are also regulated by miR-21-5p in clinical samples, indicating that these genes are bona fide targets of miR-21-5p in GC cells.

\section{Discussion}

At present, the reversal of drug resistance largely determines the efficacy of successful cancer treatment in the clinic $(35,36)$. One of the mechanisms accounting for acquired drug resistance is failure to undergo apoptosis in response to the drugs (37-39). The present study demonstrated that miR-21-5p is upregulated in DOX-resistant GC cell lines and GC patients, particularly in recurrent cases, which implies that miR-21-5p is involved in DOX resistance. Knockdown of miR-21-5p enhanced sensitivity and promoted DOX-induced apoptosis in SGC7901/DOX cells. An in-depth examination of the inverse correlation between PTEN or TIMP3 expression and miR-21-5p in SGC7901 cells and in the sufficiently large patient cohort indicated that these targets are involved in DOX resistance. The results provide novel evidence regarding the implication of miR-21-5p in DOX resistance of GC and suggest a significant association of miR-21-5p with GC patient prognosis.

Previous studies have reported that miR-21-5p participates in the tumorigenesis of several cancer types. Yan et al (40) and $\mathrm{Wu}$ et al (41) reported that the dysregulated expression of miR-21 is correlated with lymph node metastasis and poor prognosis in breast cancer and colorectal cancer, respectively. It has been reported that overexpression of miR-21 predicts poor survival of non-small-cell lung cancer patients and inhibits apoptosis through the regulation of the Ras/mitogen-associated protein kinase kinase/extracellular signal-regulated protein kinase pathway (42). Furthermore, it has been reported that miR-21-5p is upregulated in patients aged $>40$ years who underwent gastrectomy for potentially curable GC (stage III) and experienced a recurrence (43). In addition, a meta-analysis study indicated that elevated miR-21 expression levels are correlated with tumor differentiation, lymph node metastasis and TNM stage in digestive tract cancer (44), which is consistent with the results of the present study.

The importance of miR-21-5p in the progression of drug resistance is well documented. Gong et al (45) reported that ectopic expression of miR-21 in HER2 ${ }^{+}$breast cancer cells conferred resistance to trastuzumab and that miR-21-specific antisense oligonucleotides reversed this resistance by inducing growth arrest through blocking the G1/S cell cycle checkpoint. 
A
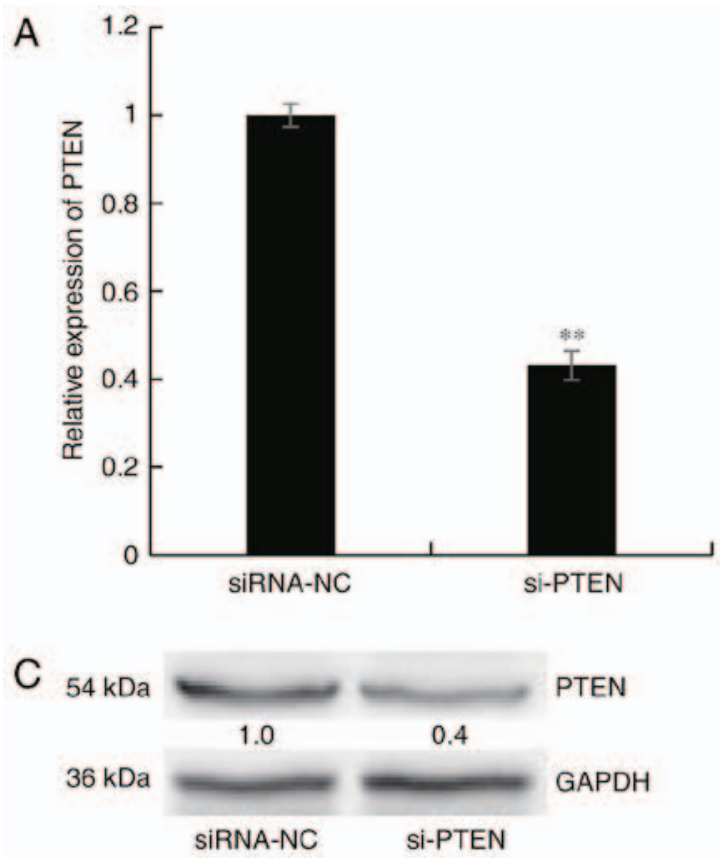

B
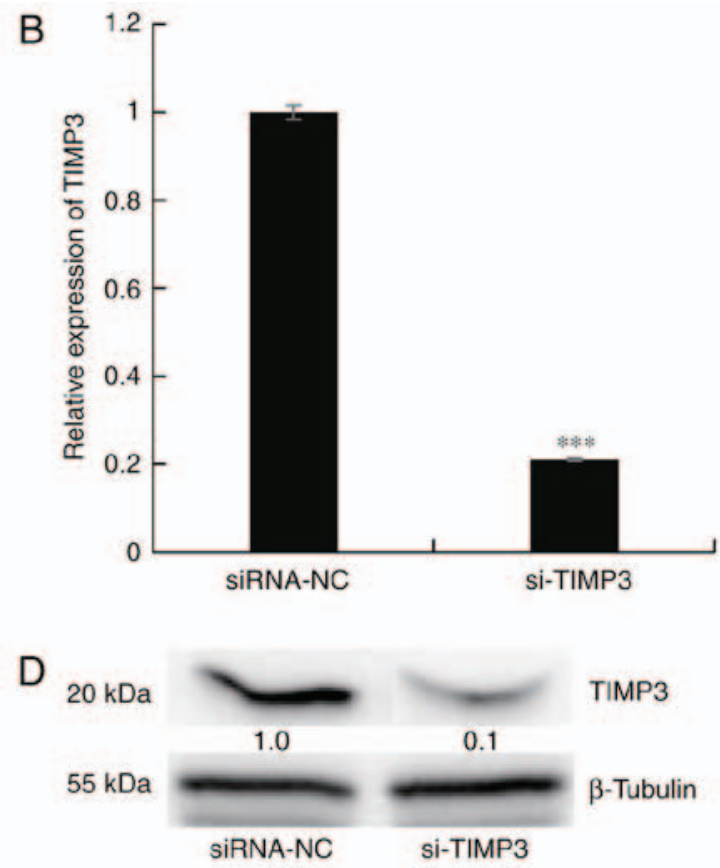

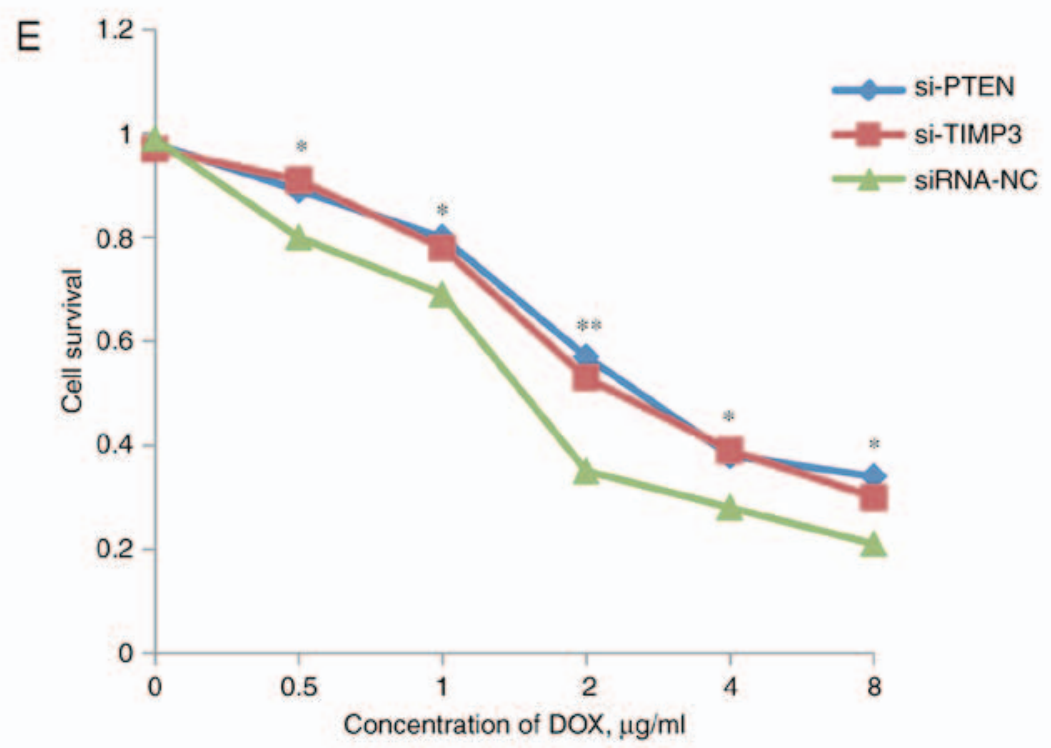

Figure 6. PTEN and TIMP3 have a key role in the chemoresistance of SGC7901 cells. (A and B) mRNA levels of PTEN and TIMP3 in SGC7901 cells were reduced after transfection with specific siRNA. (C and D) The protein expression of PTEN and TIMP3 in SGC7901 cells was reduced after transfection with specific siRNA. (E) A cell counting kit-8 assay was performed to detect the effect of siRNA-mediated PTEN and TIMP3 knockdown on the viability of SGC7901 cells. ${ }^{*} \mathrm{P}<0.05,{ }^{* *} \mathrm{P}<0.01$ and ${ }^{* * *} \mathrm{P}<0.001$ vs. miR-NC. PTEN, phosphatase and tensin homologue; TIMP3, tissue inhibitor of matrix metalloproteinases 3; siRNA, small interfering RNA; miR, microRNA; NC, negative control; DOX, doxorubicin.

Tomimaru et al (46) reported that anti-miR-21 rendered hepatocellular carcinoma cells sensitive to 5-fluorouracil by targeting PTEN and programmed cell death protein (PDCD)4. Consistent with these results, Yang et al (47) demonstrated that compared with the parental SGC7901 cell line, miR-21 was upregulated in the cisplatin (DPP)-resistant SGC7901/DDP cell line, and knockdown of miR-21 markedly increased the anti-proliferative effects and induced apoptosis by DPP through targeting PTEN. A previous study reported that miR-21 was upregulated in the paclitaxel-resistant cell line SGC7901/paclitaxel and may modulate sensitivity to paclitaxel-mediated P-glycoprotein expression (48). In the present study, SGC7901/DOX cells did not display marked
DOX resistance when miR-21-5p expression was increased. This may be due to following aspects: The elevated expression levels of miR-21-5p may not directly translate to elevated DOX resistance, and miR-21-5p may influence the expression of certain other genes and may be associated with the resistance to other drugs. For instance, various other studies have reported that miR-21-5p was associated with DPP resistance of gastric cancer cells $(47,49)$. Furthermore, the increased resistance to DOX was not entirely due to the elevation of miR-21-5p, and is probably regulated by additional signaling pathways, including the inhibition of P-glycoprotein expression and activity, or via AKT-mediated upregulation of multidrug resistance-associated protein $1(50,51)$. All of the 
A

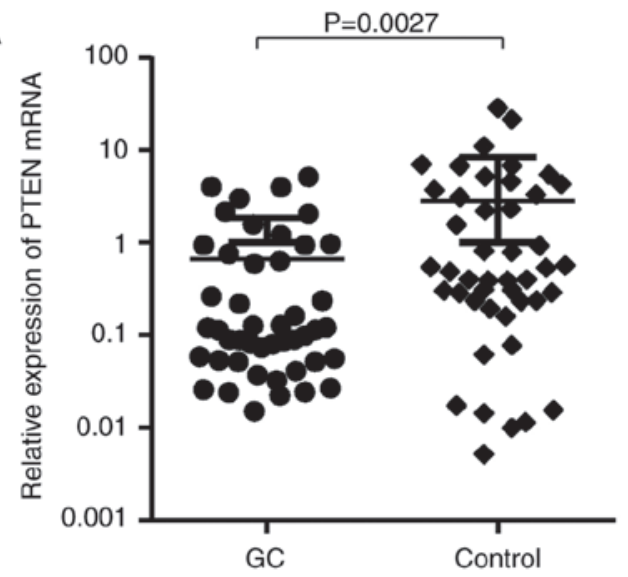

C

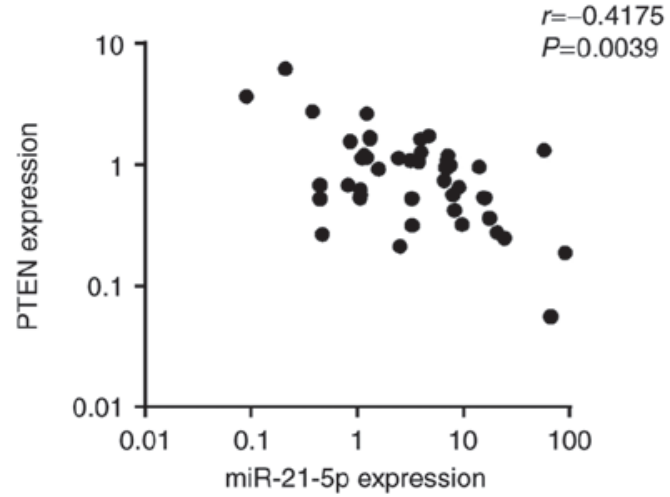

B

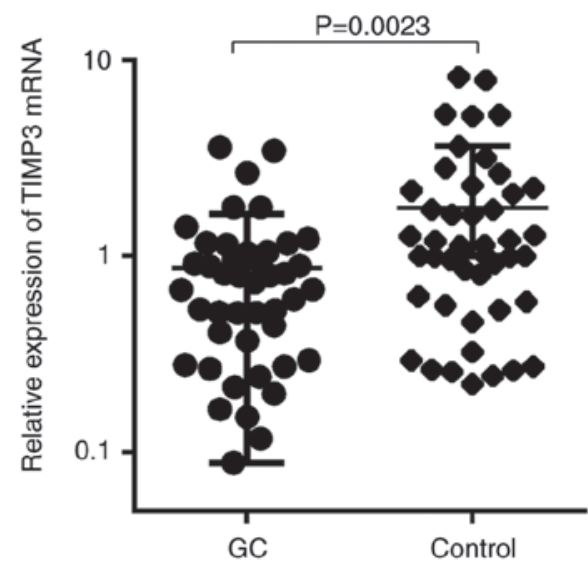

D

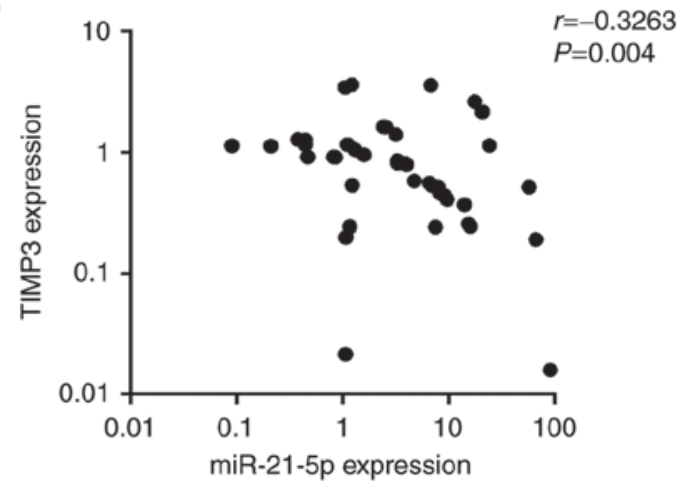

Figure 7. PTEN and TIMP3 are downregulated in GC tumor tissues, which negatively correlates with miR-21-5p levels. (A and B) A reverse transcription quantitative-polymerase chain reaction assay was used to measure the expression levels of PTEN and TIMP3 in GC samples and matched adjacent normal tissues. (C) A statistically significant negative correlation between the expression levels of miR-21-5p and PTEN was observed in GC samples ( $\mathrm{r}=-0.4175$, $\mathrm{P}=0.0039$ ). (D) A statistically significant negative correlation between the expression levels of miR-21-5p and TIMP3 was observed in GC samples ( $\mathrm{r}=-0.3263$, $\mathrm{P}=0.004)$. GC, gastric cancer; PTEN, phosphatase and tensin homologue; TIMP3, tissue inhibitor of matrix metalloproteinases 3; miR, microRNA.

above suggests that the mechanism of drug resistance is highly complex, while it is indicated that miR-21-5p may have an important role in the multidrug resistance of cancer cells.

It is broadly accepted that certain miRNAs regulate a large number of protein-coding genes during cell apoptosis. For instance, PDCD, apoptotic protease-activating factor 1, Fas ligand and B-cell lymphoma-2 (Bcl-2) have all been proven to be targets of miR-21-5p that are associated with apoptotic signaling (46,52-54). Consistent with these results, the present study demonstrated that miR-21-5p reduced apoptosis and enhanced survival of GC cells in the presence of DOX through inhibition of the expression of PTEN, as well as TIMP3, which is known to induce apoptosis and act as a tumor suppressor gene.

PTEN is a tumor suppressor gene that suppresses the proliferation, invasion and metastasis of tumor cells and induces tumor cell apoptosis (55). PTEN-mediated apoptosis in tumors is regulated by numerous canonical signaling pathways, among which the phosphoinositide-3 kinase/AKT/mammalian target of rapamycin pathway is of high interest. Activation of this pathway protects various cell types from apoptosis that is induced by withdrawal of survival factors $(56,57)$, induces the expression of anti-apoptotic $\mathrm{Bcl}-2$, and phosphorylates and inactivates the pro-apoptotic Bcl-2 family member Bcl-2-associated death promoter, which induces the expression of genes that are critical for cell death. The imbalance between $\mathrm{Bcl}-2$ and $\mathrm{Bcl}-2$-associated $\mathrm{X}$ protein may trigger apoptosis (58). TIMP3, a natural metalloproteinase inhibitor, is always silenced in human cancers. Pertinent studies have identified TIMP3 to be a critical regulator of cell death and survival. Two major pathways, p38 and Notch, were activated in the livers of $\mathrm{TIMP}^{-/}$mice (59). p38 negatively regulates cell cycle progression, facilitating DNA repair by inducing $\mathrm{p} 21$ or directly activating p53 $(60,61)$, while Notch signaling, via p53 and p21 activation, couples enhanced cell cycle arrest and senescence with tumor cell differentiation to inhibit tumorigenesis (62). The present results indicated that miR-21-5p regulates drug resistance and cell apoptosis in GC by targeting the tumor suppressors PTEN and TIMP3, and then affect the downstream signaling pathways. In future studies, specific knockdown or inhibition of individual pathways may provide a deeper understanding of these interactions.

The present study is limited by its lack of animal experiments, which would have provided more powerful evidence for implementation of the results in drug therapy $(63,64)$. However, the present study employed various experimental methods and combined clinical data for analysis in the present study. Similar studies have been performed previously, which used identical methods to verify the effect of a gene or protein on tumor cell resistance to certain drugs $(65,66)$. A future study by our group will assess the function of miR-21-5p in a mouse model. 
The present study underscored the value of miR-21-5p in DOX resistance of GC cells. It is worth noting that the increased resistance of GC cells was not consistent with changes in miR-21-5p, which implies that a complex regulation network exists in DOX-resistant GC cells.

In conclusion, miR-21-5p expression was upregulated in DOX-resistant GC cells and patient tissue samples. Reduction of miR-21-5p levels improved the sensitivity of GC cells to DOX-based chemotherapy through directly upregulating PTEN and TIMP3, suggesting that an appropriate combination of DOX with miR-21-5p antagonism may represent a potential strategy for GC treatment.

\section{Acknowledgements}

This work was supported by the Projects of International Cooperation and Achievements Management Application of Nanchang City (grant no. KJHZ-YY-002).

\section{Competing interests}

The authors declare that they have no competing interests.

\section{References}

1. Karimi P, Islami F, Anandasabapathy S, Freedman ND and Kamangar F: Gastric cancer: Descriptive epidemiology, risk factors, screening, and prevention. Cancer Epidemiol Biomarkers Prev 23: 700-713, 2014

2. Ali Z, Deng Y and Ma C: Progress of research in gastric cancer. J Nanosci Nanotechnol 12: 8241-8248, 2012.

3. Kikuchi S, Kaibe N, Morimoto K, Fukui H, Niwa H, Maeyama Y, Takemura M, Matsumoto M, Nakamori S, Miwa $\mathrm{H}$, et al Overexpression of Ephrin A2 receptors in cancer stromal cells is a prognostic factor for the relapse of gastric cancer. Gastric Cancer 18: 485-494, 2015.

4. Garrido M, Fonseca PJ, Vieitez JM, Frunza M and Lacave AJ: Challenges in first line chemotherapy and targeted therapy in advanced gastric cancer. Expert Rev Anticancer Ther 14: 887-900, 2014.

5. Di Lauro L, Vici P, Belli F, Tomao S, Fattoruso SI, Arena MG, Pizzuti L, Giannarelli D, Paoletti G, Barba M, et al: Docetaxel, oxaliplatin, and capecitabine combination chemotherapy for metastatic gastric cancer. Gastric Cancer 17: 718-724, 2014.

6. Ruffell B and Coussens LM: Macrophages and therapeutic resistance in cancer. Cancer Cell 27: 462-472, 2015.

7. Zou HY, Friboulet L, Kodack DP, Engstrom LD, Li Q, West M, Tang RW, Wang H, Tsaparikos K, Wang J, et al: PF-06463922, an ALK/ROS1 inhibitor, overcomes resistance to first and second generation ALK inhibitors in preclinical models. Cancer Cell 28: 70-81, 2015.

8. Bartel DP: MicroRNAs: Genomics, biogenesis, mechanism, and function. Cell 116: 281-297, 2004.

9. Adams CM, Hiebert SW and Eischen CM: Myc induces miRNA-mediated apoptosis in response to HDAC inhibition in hematologic malignancies. Cancer Res 76: 736-748, 2016.

10. Palmbos PL, Wang L, Yang H, Wang Y, Leflein J, Ahmet ML, Wilkinson JE, Kumar-Sinha C, Ney GM, Tomlins SA, et al: ATDC/TRIM29 drives invasive bladder cancer formation through miRNA-mediated and epigenetic mechanisms. Cancer Res 75: 5155-5166, 2015.

11. Zhang H, Pu J, Qi T, Qi M, Yang C, Li S, Huang K, Zheng L and Tong Q: MicroRNA-145 inhibits the growth, invasion, metastasis and angiogenesis of neuroblastoma cells through targeting hypoxia-inducible factor 2 alpha. Oncogene 33: 387-397, 2014.

12. Henao-Mejia J, Williams A, Goff LA, Staron M, Licona-Limón P, Kaech SM, Nakayama M, Rinn JL and Flavell RA: The microRNA miR-181 is a critical cellular metabolic rheostat essential for NKT cell ontogenesis and lymphocyte development and homeostasis. Immunity 38: 984-997, 2013
13. Huang E, Liu R and Chu Y: miRNA-15a/16: As tumor suppressors and more. Future Oncol 11: 2351-2363, 2015.

14. Xie SY, Li YJ, Wang PY, Jiao F, Zhang S and Zhang WJ: miRNA-regulated expression of oncogenes and tumor suppressor genes in the cisplatin-inhibited growth of K562 cells. Oncol Rep 23: 1693-1700, 2010.

15. Voorhoeve PM, le Sage C, Schrier M, Gillis AJ, Stoop H, Nagel R, Liu YP, van Duijse J, Drost J, Griekspoor A, et al: A genetic screen implicates miRNA-372 and miRNA-373 as oncogenes in testicular germ cell tumors. Cell 124: 1169-1181, 2006.

16. Xue J, Chi Y, Chen Y, Huang S, Ye X, Niu J, Wang W, Pfeffer LM, Shao ZM, Wu ZH and Wu J: MiRNA-621 sensitizes breast cancer to chemotherapy by suppressing FBXO11 and enhancing p53 activity. Oncogene 35: 448-458, 2016.

17. Xu C, Xie S, Song C, Huang L and Jiang Z: Lin 28 mediates cancer chemotherapy resistance via Regulation of miRNA signaling. Hepatogastroenterology 61: 1138-1141, 2014.

18. Massoner P, Thomm T, Mack B, Untergasser G, Martowicz A, Bobowski K, Klocker H, Gires O and Puhr M: EpCAM is overexpressed in local and metastatic prostate cancer, suppressed by chemotherapy and modulated by MET-associated miRNA-200c/205. Br J Cancer 111: 955-964, 2014.

19. Wang Y, Liu C, Luo M, Zhang Z, Gong J, Li J, You L, Dong L, Su R, Lin H, et al: Chemotherapy-induced miRNA-29c/Catenin- $\delta$ signaling suppresses metastasis in gastric cancer. Cancer Res 75: 1332-1344, 2015.

20. Kumar S, Keerthana R, Pazhanimuthu A and Perumal P: Overexpression of circulating miRNA-21 and miRNA-146a in plasma samples of breast cancer patients. Indian J Biochem Biophys 50: 210-214, 2013.

21. Zhang HL, Yang LF, Zhu Y, Yao XD, Zhang SL, Dai B, Zhu YP, Shen YJ, Shi GH and Ye DW: Serum miRNA-21: Elevated levels in patients with metastatic hormone-refractory prostate cancer and potential predictive factor for the efficacy of docetaxel-based chemotherapy. Prostate 71: 326-331, 2011.

22. Wang XC, Wang W, Zhang ZB, Zhao J, Tan XG and Luo JC: Overexpression of miRNA-21 promotes radiation-resistance of non-small cell lung cancer. Radiat Oncol 8: 146, 2013.

23. Gao W, Lu X, Liu L, Xu J, Feng D and Shu Y: MiRNA-21: A biomarker predictive for platinum-based adjuvant chemotherapy response in patients with non-small cell lung cancer. Cancer Biol Ther 13: 330-340, 2012.

24. Song J, Bai Z, Zhang J, Meng H, Cai J, Deng W, Bi J, Ma X and Zhang Z: Serum microRNA-21 levels are related to tumor size in gastric cancer patients but cannot predict prognosis. Oncol Lett 6: 1733-1737, 2013.

25. Dillhoff M, Liu J, Frankel W, Croce C and Bloomston M: MicroRNA-21 is overexpressed in pancreatic cancer and a potential predictor of survival. J Gastrointest Surg 12: 2171-2176, 2008.

26. Mydlarz W, Uemura M, Ahn S, Hennessey P, Chang S, Demokan S, Sun W, Shao C, Bishop J,Krosting J, et al: Clusterin is a gene-specific target of microRNA-21 in head and neck squamous cell carcinoma. Clin Cancer Res 20: 868-877, 2014.

27. Fulci V, Chiaretti S, Goldoni M, Azzalin G, Carucci N, Tavolaro S, Castellano L, Magrelli A, Citarella F, Messina M, et al: Quantitative technologies establish a novel microRNA profile of chronic lymphocytic leukemia. Blood 109: 4944-4951, 2007.

28. Paik WH, Kim HR, Park JK, Song BJ, Lee SH and Hwang JH: Chemosensitivity induced by down-regulation of microRNA-21 in gemcitabine-resistant pancreatic cancer cells by indole-3-carbinol. Anticancer Res 33: 1473-1481, 2013.

29. Wei X, Wang W, Wang L, Zhang Y, Zhang X, Chen M, Wang F, Yu J, Ma Y and Sun G: MicroRNA-21 induces 5-fluorouracil resistance in human pancreatic cancer cells by regulating PTEN and PDCD4. Cancer Med 5: 693-702, 2016.

30. Valeri N, Gasparini P, Braconi C, Paone A, Lovat F, Fabbri M, Sumani KM, Alder H, Amadori D, Patel T, et al: MicroRNA-21 induces resistance to 5 -fluorouracil by down-regulating human DNA MutS homolog 2 (hMSH2). Proc Natl Acad Sci USA 107: 21098-21103, 2010

31. Davies GF, Juurlink BH and Harkness TA: Troglitazone reverses the multiple drug resistance phenotype in cancer cells. Drug Des Devel Ther 3: 79-88, 2009.

32. Schmittgen TD and Livak KJ: Analyzing real-time PCR data by the comparative C(T) method. Nat Protoc 3: 1101-1108, 2008.

33. Clément T, Salone V and Rederstorff M: Dual luciferase gene reporter assays to study miRNA function. Methods Mol Biol 1296: 187-198, 2015. 
34. Li SC, Liao YL, Ho MR, Tsai KW, Lai CH and Lin WC: miRNA arm selection and isomiR distribution in gastric cancer. BMC Genomics 13 (Suppl 1): S13, 2012.

35. Oddo D, Sennott EM, Barault L, Valtorta E, Arena S, Cassingena A, Filiciotto G, Marzolla G, Elez E, van Geel RM, et al: Molecular landscape of acquired resistance to targeted therapy combinations in BRAF-mutant colorectal cancer. Cancer Res 76: 4504-4515, 2016.

36. Zhao Y, Khanal P, Savage P, She YM, Cyr TD and Yang X: YAP-induced resistance of cancer cells to antitubulin drugs is modulated by a Hippo-independent pathway. Cancer Res 74: 4493-4503, 2014.

37. Mueller T, Voigt W, Simon H, Fruehauf A, Bulankin A, Grothey A and Schmoll HJ: Failure of activation of caspase-9 induces a higher threshold for apoptosis and cisplatin resistance in testicular cancer. Cancer Res 63: 513-521, 2003.

38. Chauhan D, Tian Z, Nicholson B, Kumar KG,Zhou B, Carrasco R, McDermott JL, Leach CA, Fulcinniti M, Kodrasov MP, et al: A small molecule inhibitor of ubiquitin-specific protease-7 induces apoptosis in multiple myeloma cells and overcomes bortezomib resistance. Cancer Cell 22: 345-358, 2012.

39. Konopleva M, Contractor R, Tsao T, Samudio I, Ruvolo PP, Kitada S, Deng X, Zhai D, Shi YX, Sneed T, et al: Mechanisms of apoptosis sensitivity and resistance to the BH3 mimetic ABT-737 in acute myeloid leukemia. Cancer Cell 10: 375-388, 2006.

40. Yan LX, Huang XF, Shao Q, Huang MY, Deng L, Wu QL, Zeng YX and Shao JY: MicroRNA miR-21 overexpression in human breast cancer is associated with advanced clinical stage, lymph node metastasis and patient poor prognosis. RNA 14: 2348-2360, 2008.

41. Wu CW, Ng SS, Dong YJ, Ng SC, Leung WW, Lee CW, Wong YN, Chan FK, Yu J and Sung JJ: Detection of miR-92a and miR-21 in stool samples as potential screening biomarkers for colorectal cancer and polyps. Gut 61: 739-745, 2012.

42. Lee HW, Lee EH, Ha SY, Lee CH, Chang HK, Chang S, Kwon KY, Hwang IS, Roh MS and Seo JW: Altered expression of microRNA miR-21, miR-155, and let-7a and their roles in pulmonary neuroendocrine tumors. Pathol Int 62: 583-591, 2012.

43. Park SK, Park YS, Ahn JY, Do EJ, Kim D, Kim JE, Jung K, Byeon JS, Ye BD, Yang DH, et al: MiR 21-5p as a predictor of recurrence in young gastric cancer patients. J Gastroenterol Hepatol 31: 1429-1435, 2016

44. Yin C, Zhou X, Dang Y, Yan J and Zhang G: Potential role of circulating MiR-21 in the diagnosis and prognosis of digestive system cancer: A systematic review and meta-analysis. Medicine (Baltimore) 94: e2123, 2015.

45. Gong C, Yao Y, Wang Y, Liu B, Wu W, Chen J, Su F, Yao H and Song E: Up-regulation of miR-21 mediates resistance to trastuzumab therapy for breast cancer. J Biol Chem 286: 19127-19137, 2011.

46. Tomimaru Y, Eguchi H, Nagano H, Wada H, Tomokuni A, Kobayashi S, Marubashi S, Takeda Y, Tanemura M, Umeshita K, et al: MicroRNA-21 induces resistance to the anti-tumour effect of interferon-alpha/5-fluorouracil in hepatocellular carcinoma cells. Br J Cancer 103: 1617-1626, 2010.

47. Yang SM, Huang C, Li XF, Yu MZ, He Y and Li J: miR-21 confers cisplatin resistance in gastric cancer cells by regulating PTEN. Toxicology 306: 162-168, 2013.

48. Jin B, Liu Y and Wang H: Antagonism of miRNA-21 Sensitizes Human Gastric Cancer Cells to Paclitaxel. Cell Biochem Biophys 72: 275-282, 2015

49. Zheng P, Chen L, Yuan X, Luo Q, Liu Y, Xie G, Ma Y and Shen L: Exosomal transfer of tumor-associated macrophage-derived miR-21 confers cisplatin resistance in gastric cancer cells. J Exp Clin Cancer Res 36: 53, 2017.

50. Wang S, Wang A, Shao M, Lin L, Li P and Wang Y: Schisandrin B reverses doxorubicin resistance through inhibiting P-glycoprotein and promoting proteasome-mediated degradation of survivin. Sci Rep 7: 8419, 2017.
51. Cao Z, Liang N, Yang H and Li S: Visfatin mediates doxorubicin resistance in human non-small-cell lung cancer via Akt-mediated up-regulation of ABCC1. Cell Prolif 50, 2017.

52. Papagiannakopoulos T, Shapiro A and Kosik KS: MicroRNA-21 targets a network of key tumor-suppressive pathways in glioblastoma cells. Cancer Res 68: 8164-8172, 2008

53. Zhu S, Si ML, Wu H and Mo YY: MicroRNA-21 targets the tumor suppressor gene tropomyosin 1 (TPM1). J Biol Chem 282: 14328-14336, 2007.

54. Sayed D, He M, Hong C, Gao S, Rane S and Yang $Z$ and Abdellatif M: MicroRNA-21 is a downstream effector of AKT that mediates its antiapoptotic effects via suppression of Fas ligand. J Biol Chem 285: 20281-20290, 2010.

55. Blumenthal GM and Dennis PA: Pten hamartoma tumor syndromes. Eur J Hum Genet 16: 1289-1300, 2008.

56. Kennedy SG, Wagner AJ, Conzen SD, Jordán J, Bellacosa A, Tsichlis PN and Hay N: The pi3-kinase/akt signaling pathway delivers an anti-apoptotic signal. Genes Dev 11: 701-713, 1997.

57. Yea SS and Fruman DA: Achieving cancer cell death with PI3K/mtor-targeted therapies. Ann N Y Acad Sci 1280: 15-18, 2013.

58. Westhoff MA, Faham N, Marx D, Nonnenmacher L, Jennewein C, Enzenmuller S, Gonzalez P, Fulda S and Debatin KM: Sequential dosing in chemo-sensitization: Targeting the PI3K/akt/mtor pathway in neuroblastoma. PLoS One 8: e83128, 2013.

59. Defamie V, Sanchez O, Murthy A and Khokha R: TIMP3 controls cell fate to confer hepatocellular carcinoma resistance. Oncogene 34: 4098-4108, 2015.

60. Han J and Sun P: The pathways to tumor suppression via route p38. Trends Biochem Sci 32: 364-371, 2007.

61. Bulavin DV and Fornace AJ Jr: p38 MAP kinase's emerging role as a tumor suppressor. Adv Cancer Res 92: 95-118. 2004.

62. Rangarajan A, Talora C, Okuyama R, Nicolas M, Mammucari C, Oh H, Aster JC, Krishna S, Metzger D, Chambon P, et al: Notch signaling is a direct determinant of keratinocyte growth arrest and entry into differentiation. EMBO J 20: 3427-3436, 2001.

63. Shibata T, Watari K, Izumi H, Kawahara A, Hattori S, Fukumitsu C, Murakami Y, Takahashi R, Toh U, Ito KI, Ohdo S, et al: Breast cancer resistance to antiestrogens is enhanced by increased ER degradation and ERBB2 expression. Cancer Res 77: 545-556, 2017.

64. Schneider C, Oellerich T, Baldauf HM, Schwarz SM, Thomas D, Flick R, Bohnenberger H, Kaderali L, Stegmann L, Cremer A, et al: SAMHD1 is a biomarker for cytarabine response and a therapeutic target in acute myeloid leukemia. Nat Med 23: 250-255, 2017.

65. Feng DD, Zhang H, Zhang P, Zheng YS, Zhang XJ, Han BW, Luo XQ, Xu L, Zhou H, Qu LH and Chen YQ: Down-regulated miR-331-5p and miR-27a are associated with chemotherapy resistance and relapse in leukaemia. J Cell Mol Med 15: 2164-2175, 2011

66. Kimura A, Ogata K, Altan B, Yokobori T, Ide M, Mochiki E, Toyomasu Y, Kogure N, Yanoma T, Suzuki M, et al: Nuclear heat shock protein 110 expression is associated with poor prognosis and chemotherapy resistance in gastric cancer. Oncotarget 7 : 18415-18423, 2016.

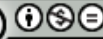

This work is licensed under a Creative Commons Attribution-NonCommercial-NoDerivatives 4.0 International (CC BY-NC-ND 4.0) License. 